\title{
Interculturalism in The Eyes of Marege Performance
}

\author{
Alif Anggara ${ }^{1}$ \\ Fakultas Desain dan Seni, Universitas Negeri Makassar
}

jurnal tari, teater, dan wayang volume 1 number 1, May 2018 page $36-42$

\begin{abstract}
The Eyes of Marege is a surreal drama which consists of two acts with fourteen scenes. It is an intercultural performance that raises the history of relations between Makassar and Aborigines in the past. The research aims to know the basic idea of creation, the concretization stages, as well as the structure and texture of the performance. This research applies a qualitative method with a sociological approach. Observations were started from DVDs of the performance and drama script of The Eyes of Marege. Data were collected from interviews with some respondents and literature study. The Eyes of Marege is inspired by folklore, myths, songs about Makassarese coming to Arnhem Land - Northern Australia to find sea cucumbers. It was the place where Julie Janson had lived for thirty years and was raised by the Yolngu family. In addition, Julie Janson got some other inspirations from several readings and personal experiences when visiting Makassar.
\end{abstract}

Keywords: Eyes of Marege; Makasarese folklore; Julie Janson

\begin{abstract}
Abstrak
Interkuluralisme dalam Pertunjukan The Eyes of Marege. The Eyes Of Marege merupakan drama absurd atau surealis yang terdiri dari dua babak dengan empat belas adegan. Penelitian ini bertujuan untuk mengetahui ide dasar penciptaan, tahapan konkretisasi, serta struktur maupun tekstur pertunjukannya. Penelitian ini menggunakan metode kualitatif dengan pendekatan sosiologi. Penelitian dilakukan dengan cara pengamatan pertunjukan dan analisis naskah drama diikuti dengan wawancara dan studi pustaka. Berdasarkan penelitian dapat disimpulkan bahwa drama ini terinspirasi dari cerita rakyat, mitos, nyanyiannyanyian tentang orang Makassar yang datang ke Arhemland - Australia Utara untuk mencari teripang. Tempat itu adalah tempat di mana Julie Janson pernah tinggal selama tiga puluh tahun dan diasuh oleh keluarga Yolngu. Drama ini dapat digolongkan sebagai pertunjukan interkultural yang mengangkat masalah sejarah hubungan antara suku Makassar dan suku Aborigin yang pernah terjalin di masa silam.
\end{abstract}

Kata kunci: Eyes of Marege; folklore Makassar; Julie Janson

\section{Introduction}

The development of internet as a media of communication enables artists to meet and work together to produce works of art in collaboration by defining symbolic, contextual, essential concepts and decoding a universal meaning. Collaboration in this paper is defined as a form of social interaction in which there are art activities to achieve common goals.

This media of communication which connects national and international artists provides a creative space for sharing ideas and combines two cultures that produce innovative

1 Correspondence: BTN Bumi Btara Gowa, Blok E1 No 5 Sungguminasa. Kabupaten Gowa Provinsi Sulawesi Selatan. E-mail: aliefanggara336@gmail.com, HP.: +6285342410689. 
performances originated from a historical relationship in the past. This has been done by Teater Kita Makassar (TKM) and Australian Performance Exchange (APE) in Julia Janson's The Eyes of Marege (TEOM) performed at the Oz Asia Festival on 27-29 September 2007 at Playhouse Adelaide Sydney Australia.

Julie Janson has made a lot of revision on this play, which has a historical background of Makassars and Aborigines encounters, after she directly observed these locals and had a discussion with Teater Kita Makassar. The presence of folklore, myths and hymns that are hereditary in society as well as some research on the history of Makassars's voyages to Aborigines became the starting point of the performance of The Eyes of Marege. In fact, the folklore or the growing oral tradition of this relationship has undergone many changes. There is no certainty of the events it contains. Moreover, with the tradition of relationships that have ended since 1907, the storyteller in general has changed the story version after two generations. The story is a piece of relationship history with inadequate informative details of the history. However, depart from the limitation of historical details, Teater Kita Makassar (TKM) and Australian Performance Exchange (APE) met and conducted thorough discussions and tried to construct the story on the basis of historical relations which is then packaged in the form of performances by presenting the strengths of both tribal traditions. Although The Eyes of Marege is based on the combination of a folklore and research findings, the characters and stories must have been dramatized in such a way as to try to sulk the intimate bond between the tribe of Makassars and the Aborigines.

Finally, it is specifically revealed to the vision of TKM and APE that expect the TEOM play performance to awaken the collective memory of the historical and cross-cultural relationships that have existed hundreds of years ago between Makassars in Indonesia and Aborigines in Australia who have fostered a true sense of brotherhood between the two tribes in the past which in turn became the inspiration for a solid foundation in building a more lasting relationship between Indonesia and Australia as a neighboring country.

What APE and TKM have done in the TEOM play performance carries an intercultural charge which was suggested by Patrice Pavis (1992: 2) as an attempt to achieve an intercultural dialectical exchange. This play performance contains two cultures touching each other, but it can have more than two different cultures that interact, stimulate and answer one's questions to others (Bakdi Soemanto, 1999: 197).

As mentioned in the background, the TEOM performances are based on oral tradition or folklore that developed in Makassar and Aboriginal community in which the spirit of relationship of both communities is packaged in a play performance. Yudiaryani writes that the presence of oral tradition in the community environment contributes quite a lot to the effort of reconstructing past messages (Yudiaryani, http://lembagateaterperempuan. com).

Patrice Pavis makes concrete stages of theatrical performances in which theatrical elements move the cultural message of the source toward the target culture. The transfer of cultural messages makes theatrical performances intertextual. Cultural transfers occur, ie between source culture to target culture through mise en scène. Patrice Pavis stated that the situation was done by forming mise en scène performances and reconstructing artistic, systematic, and technical artistic creation steps. Pavis mentions also the two elements that must be considered in shaping the mise en scène are the culture of the source and the target culture. The stages consist of five stages: The first stage (T0) is idea identification. This stage is within the cultural area of the source tracked by the artist. The second stage (T1), namely artistic observation, is the artist effort to concoct ideas through artistic form. The third stage (T2) is artist perspective stage. The fourth stage (T3) is the staging concretization stage. The fifth stage (T4) is the concretization of the audience reception. 


\section{Discussion}

1. Idea Identification Stage (T0) of The Eyes of Marege

This stage is within the cultural source area of the the artist. The idea is still abstract and stays in the players' minds so this idea has not had a clear form yet. However, this stage is the source of the play performance. It is also a culture source that becomes a message to the recipients (Yudiaryani, 2015: 34).

The Eyes of Marege (TEOM) was created through a long process. The first part of the manuscript The Corocodile Hotel was inspired when Julie learned and listened to the stories of the Makassars while teaching drama and English on Elcho Island. He was fascinated to hear about Muslim men from Makassar, who came to trade in northern Australia, and they had no desire to colonize or attack the Yolngu, indigenous Australians, as the Europeans or the British did.
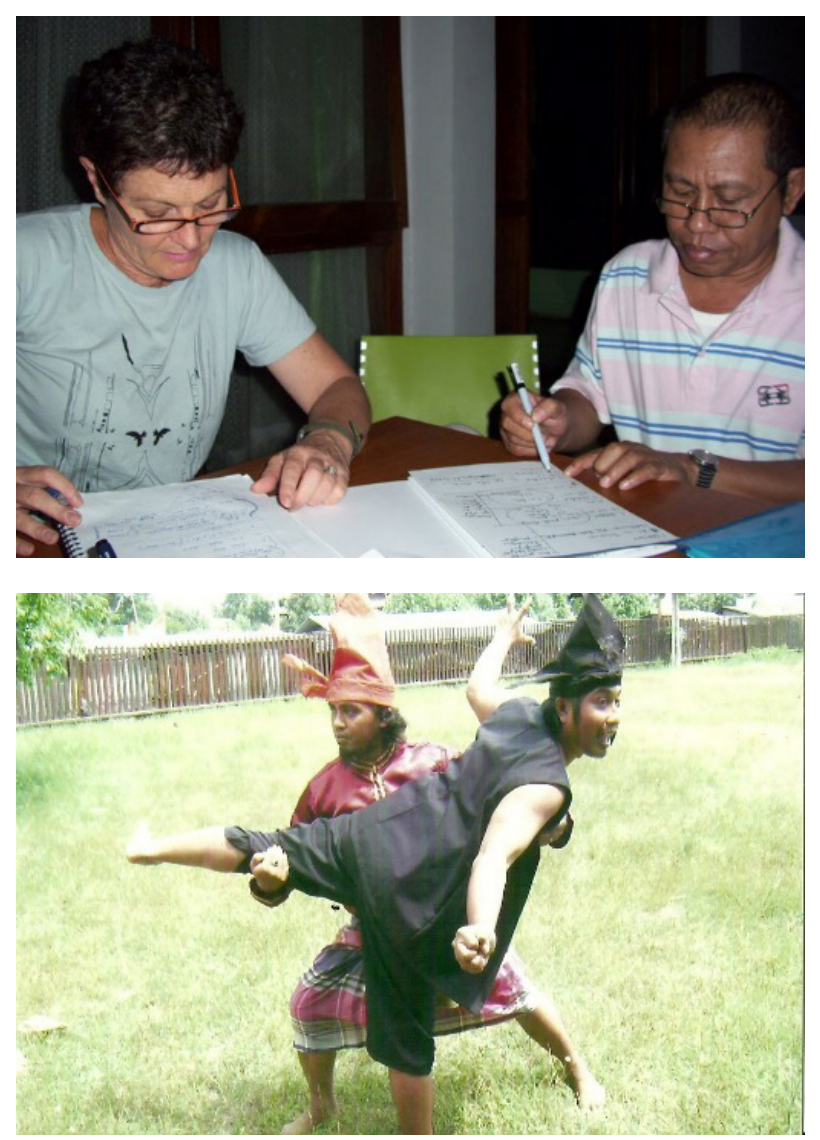

Figure 1. Workshop and exploration process. (Source: Teater Kita Makassar)
On one occasion she finally went to Makassar. There she saw a black triangle on the ridge of Toraja's house which was the same as the triangle design she had seen in Arnhem Land. Julie then walked in a harbor in Makassar and saw a pirate-like man who were laughing at her staring at her blond hair and instantly helped her rise onto their ship dock. Julie also bought an antique Makassar sword and took it home to Arnhem Land. Arriving at Arnhem Land, an old man had already waited for Julie and she gave away the sword she was carrying. The old man then smeared the sword with sugar. The next day he tied the sword around his waist and performanceed it in the midst of the Yolngu people. Julie noticed they were proud of having something valuable from Makassar.

The historical facts of Makassars and Aborigines in the past have, to date, been able to be expressed only through studies and never expressed in art, especially drama or theater. Therefore, it is natural
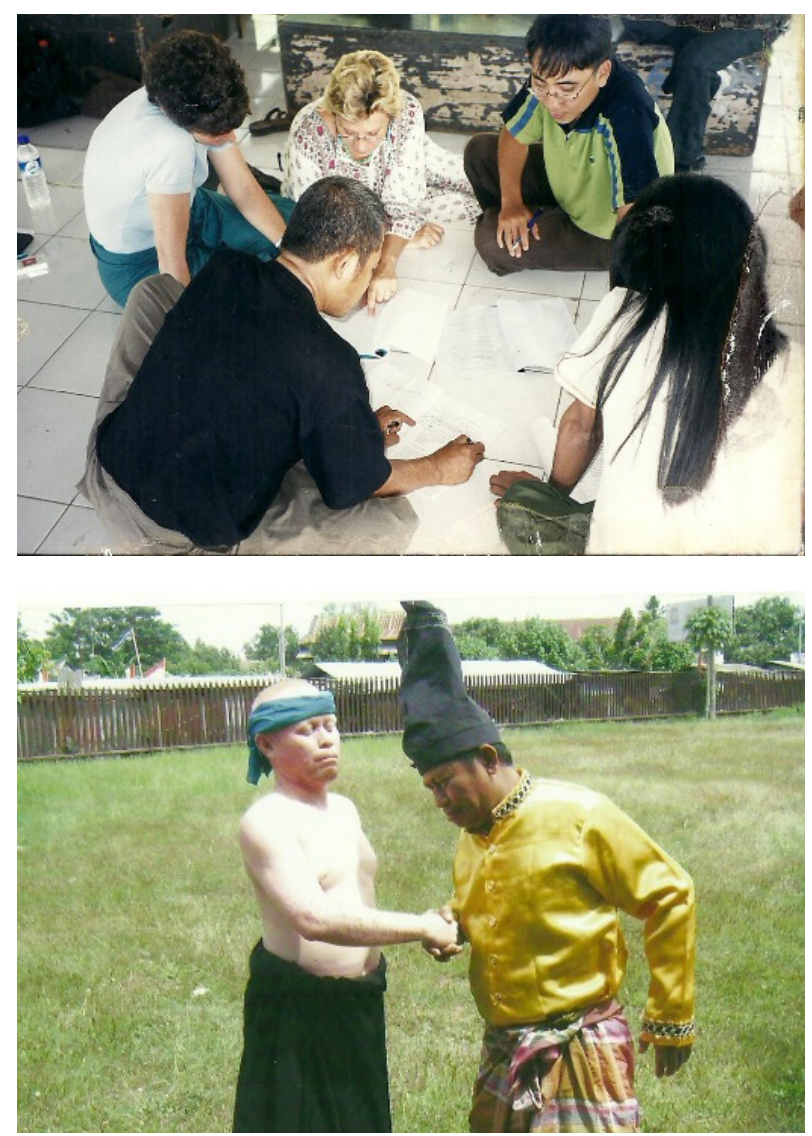
that Julie, as a teacher who is also a researcher in the field of literature and theater is inspired by stories based on historical background, culture, trade, love, marriage, and brotherhood of these two communities and tries to process them in the form of works art.

\section{Artistic Observation Stage (T1)}

The second stage (T1) is artistic observation. This stage is a textual concretization. Similar to the fact of folklore with oral traditions everywhere, the folk tale about the ties between Makassars and Aborigines has undergone many changes particularly about the certainty of the events.

\section{Artists' Perspective Stage (T2)}

This stage is the stage of drama concretization, namely the effort of adjustment between artists' exploration with their perspective. The Eyes of Marege (TEOM) was a collaborative work as both the content of the manuscripts and themes were built together in the $\mathrm{Oz}$ Asia Festival which raised the issue of multiculturalism and cross-cultural. The TEOM performance also carries a charge of interculturalism as Pavis (1992: 2), suggested that it was an attempt to achieve an intercultural dialectical exchange. This performance indicates that it contains two cultures touching each other, but it can have more than two different cultures that interact, stimulate and answer one's questions to others (Soemanto 1999: 197).

Since the time of Aristotle, each play consists of five acts. In the Renaissance many dramas were written in the structure of five acts, for it was considered an 'ideal' form. Perhaps it is associated with five stages that form a dramatic path, namely: (1) introduction, recognition, or exposition; (2) complication, exertion, or complication; (3) problem raising, climax, or decisive moment: (4) resolution, decrease, divorce, or settlement; and (5) the end of the
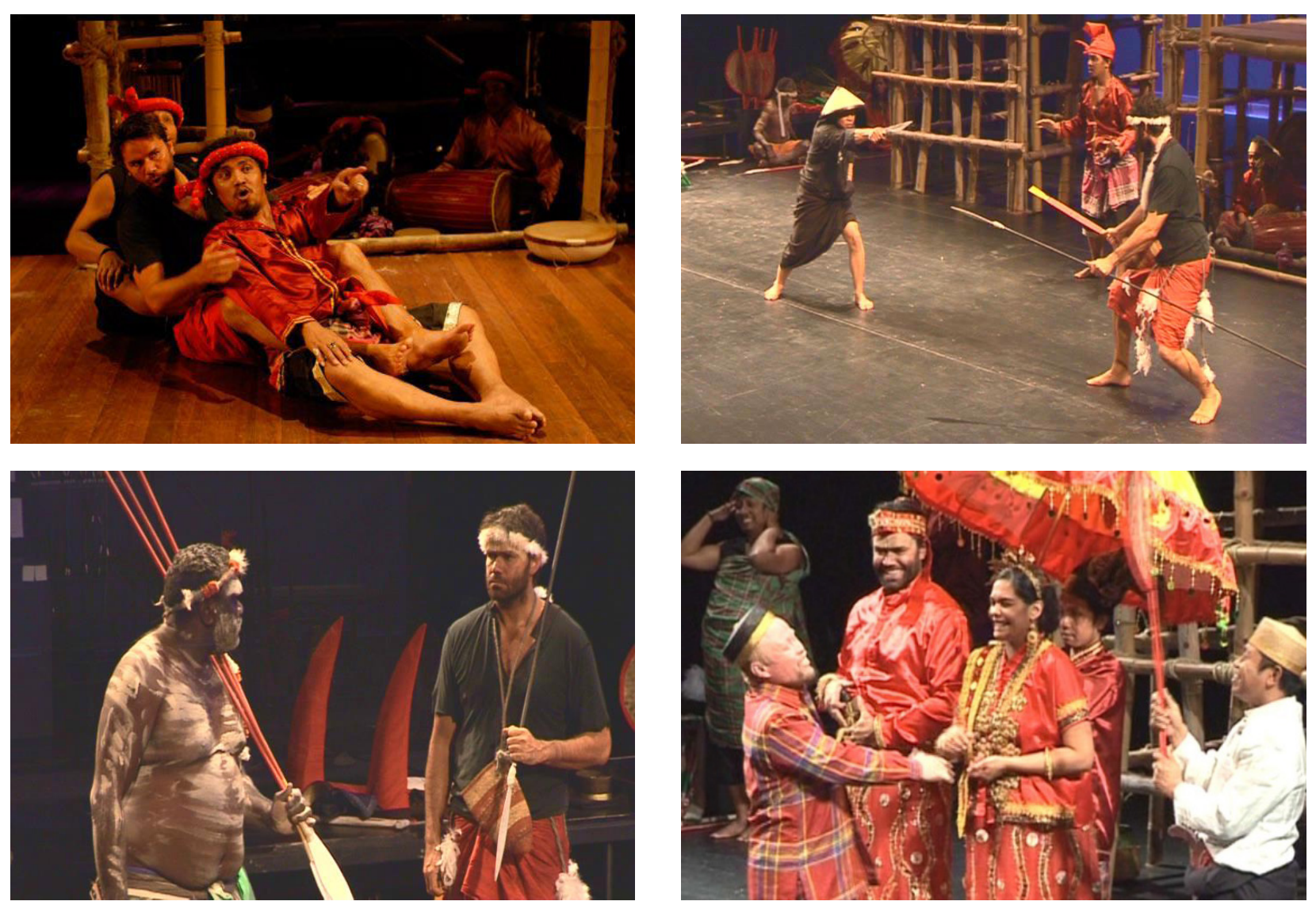

Figure 2. Some acts in The Eyes of Marege. (Source: Teater Kita Makassar) 
story, problem solving, conclusions, or catastrophes (Dietrich 1955: 32-4).

\section{Staging Concretization Stage (T3)}

Transfer of ideas is done through the concretization of staging. This stage is an effort to bring the artist's perspective to the recipient through the elements of the performance. At this stage the writing is synchronized with a performance texture consisting of dialogue, mood/atmosphere, spectacles.

The correlation of scientific findings and folklore about the ties of Makassars and Aborigines community that have existed in the TEOM structure is significant with the existing history although there is a time and place difference in the story. But here is the creativity of Julie Janson in constructing the story on the basis of historical relations of the past which is then packaged in the form of performances by presenting the forces of the tribal tradition and dramatizing in such a way as an attempt to try to sulk the intimate bond between Makassars and Aborigines. History and folklore found are then constructed in the structure of the TEOM manuscript as follows: 1) Julie took the scene on the coast of the island of Bimo, Arnhem Land, Northern Territory, 1905 as has been disclosed by Elizabeth Milmilany Phurrkay who wrote about the island of Elcho which was first visited by the people of Makassar. 2) The year of the event was taken from 1905 which approached the end of the two coummunities' relationship in 1907. 3) The Sailing of Makassar people to Marege looking for sea cucumbers is in accordance with several research findings including: K.J. McIntyre in his book "The Sectret Discovery of Australia", Bobby Dhalmurrawuy Gaykamang, Bobby Wunyimarra Ganambar, Barbara Laklak Ganambarr, Rarriwuy Marika, Elizabeth Milmilany Phurrkay, Valerie Aumann, and Teddy Portaminny. 4) The exchange of objects by Makassars and Aborigines is also described in the writings of Elizabeth Milmilany Phurrkay which tells of Makassars people carrying tobacco, knives, pennies and pearls. These goods were originally traded but then they would exchange them with Aborigines women. This can be indirectly attributed to the scene when Ahmad came to Aborigines people and gave gifts of the goods to Dhalawal's father. As for Bobby Dhalmurrawuy Gaykamangu is told in the story he and the Makassars (or Ahmad) often go out together looking for icons/ cucumbers, eat together, and exchange for certain objects. This is in accordance with the last scene when Makassars and Aborigines exchanged objects. 5) Marriage between Makassars and Aborigines people can also be found in Barbara Laklak Ganambarr's script telling her grandfather's story that some Makassars married Aborigines women and brought them back to Indonesia. Additionally, Elizabeth Milmilany Phurrkay in her story found the statement that they (Makassars) brought many Aboriginal women to Makassar. One of them is Garngarr, living in Makassar. That is why there are many Makassars marriages with Aborigines people. 6) The arrival of Aborigines to Makassar has also been found in Rarriwuy Marika's writings. The article tells us that one day Djalatjirri went to Makassar with the people of Makassar and came back again. This man is the father of Gadalming. There were two people who went there and they were brothers. The other person's name is Domi. 7) The Makassars and Aborigines people's friendship was reported in Barbara Laklak Ganambarr's article that Aboriginal people asked Makassars to stay and sleep with them and other tribes. They made friends with one another like brothers and think of their relationship as family. Valerie Aumann writes that the people of Makassar do not make trouble, and they are very friendly, giving rice to eat. 8) The shooting of a Makassar boat by the Australian government written by Teddy Portaminny suggests that the relationships that have existed for years have stalled. A Makassar boat, Alle Polea, made its last 
voyage. Unfortunately for this fisherman, the boat broke. His captain was named Oesing (Yatim, 1991: 64-65).

\section{Concretization of the Audience Reception Stage (T4)}

This stage is the concretization of acceptance, that is a trial on the creation concretization approach to the elements of the play to the recipient's taste. The taste of the audience meets the taste of the artist. There was a meeting between artists' art creativity and the aesthetic quality of the audience.

Generally Australian audiences are quite positive watching the TEOM. At the end of the performance the audience's applause witnessed the success of the TEOM performance. After the players paid their last respects, the audience's applause did not stop until the players and supporters of the event returned to the stage and paid their respects a second time. This is an evidence to the success of the performance. They are very curious about the workings of Teater Kami Makasar as well as the story of a meeting between Makassars merchants and indigenous peoples of Northeast Arnhem Land. This is something new for Australians. For young Aborigines people, the story of the intimate relationship between Makassars

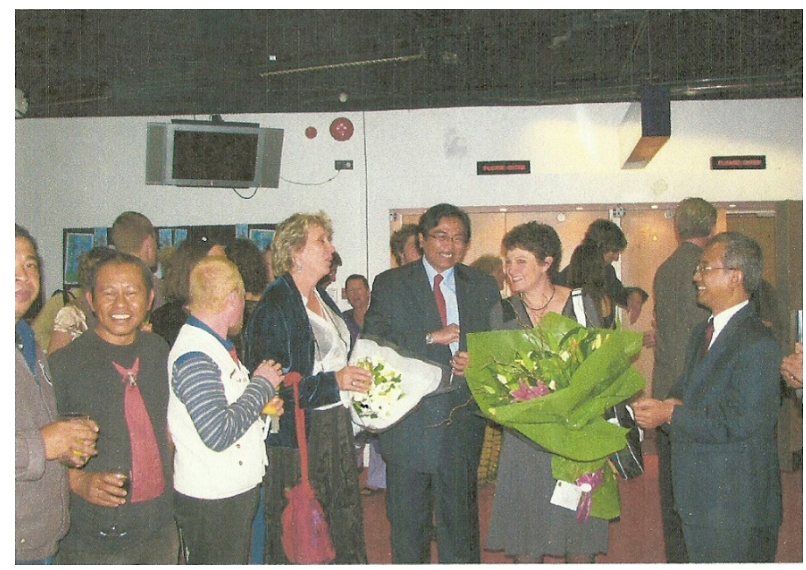

Figure 3. Consulate General of RI-Sydney, Sudaryomo Hartosudarmo together with Atdikbud KBRI (Embassy of the Republic of Indonesia) Canberra, and some staff Consulate General of Republic of Indonesia Sydney after watching the play.

(Source: Teater Kita Makassar). and Aborigines is only derived from the stories of their parents and from research books. Never has the story been staged in a theater form like TEOM.

From the meeting in the TEOM performance, there was an exchange of knowledge of Makassars and Aborigines culture. They are directly engaged in a close emotional relationship. According to Ram, when the performance was over, many spectators were curious about musical instruments, costumes and property. They then came up to see the performers and staff of the event to do a question and answer about the process undertaken by TKM and APE. Cultural interaction between two tribes in Indonesia and Australia was successfully packed and performed in a theater performance entitled The Eyes of Merege (TEOM). Consulate General of RI-Sydney, Sudaryomo Hartosudarmo together with Atdikbud KBRI (Embassy of the Republic of Indonesia) Canberra, and some staff Consulate General of Republic of Indonesia Sydney also witnessed the performances. According to Ram, the Consulate in Sydney is very supportive of organizing this activity by providing accommodation and consumption during the preparation and staging. This is sought because it realizes the importance of cultural cooperation to deepen mutual understanding between Indonesia and Australia.

TEOM was also witnessed by the Indonesian Ambassador to Australia and he was very impressed. Sally and Ram had applied for funds at the Department of Foreign Affairs for a tour to Indonesia to stage the TEOM but there had no definitive answer in the submission.

Finally, the TEOM performance also carries a charge of interculturalism as stated by Pavis (1992: 2) in an attempt to achieve an intercultural dialectical exchange. This performance contains two cultures touching each other in it, but it can have more than two different cultures that interact, stimulate and answer one's 
questions to others (Bakdi Soemanto in Journal of MSPI, 1999: 197). TKM and APE which from different cultural backgrounds have resulted understanding of each other's challenges and problems, as well as professional judgment on each of its works and artists.

\section{Conclusion}

There are some conclusions as follows. Idea Identification Stage (T0) comprises Julie Janson's basic idea that created TEOM based on inspiration from history, life experiences, folklore and the conditions of society at that time. Artistic observation stage (T1) consists of the exploration process of APE and TKM. The exploration results many forms of setting and acts which are taken from both traditions. Artists' perspective stage (T2) founds that TEOM is an intercultural performance which achieves dialectic exchange between two cultures between Makassars and Aborigines. Staging concretization stage (T3) is the elements creation in TEOM performance. Concretization of the audience reception stage performances the how enthusiastic the audience was after the performance, how they came to the TEOM performers and crew and did a discussion about the collaboration process undertaken by APE and TKM.

The Eyes of Marege (TEOM) performance cases the history of trade, socio-cultural, fraternal and marital ties of Makassars and Aborigines people who have existed in the past. It contributed to the history of the two communities' relation that can not only be known through books, articles or artifacts but through the performing arts especially theatrical performances. In addition, what TKM and APE have done in the TEOM performance can be a collective memory for both countries (Indonesia and Australia) about the harmonious relationships that have existed.

TEOM is a two-tier theater performance of two countries which is intercultural performances that seek to achieve a dialectical exchange of two cultures that interact, touch, and work together in an attempt to forge harmonious relationships that have existed in the past.

\section{References}

Cauvel, Richard. 2005. Indonesia-Australia tantangan dan kesempatan dalam hubungan politik bilateral. Jakarta. Universitas Indoneia(UI) dan Granit

Dayakisni Tri, Yuniardi Salis. 2008. Psikologi Lintas Budaya. Malang: Universitas Muahammadiayah Malang.

Dietrch, E. John. 1953. Play Diretion. America: Englewood Cliff NJ.

Harymawan, RMA.1993. Dramaturgi. Bandung: Remaja Rosdakarya.

Kernodle, George. 1967. Invitation to the Theatre. New York: Harcourt. Brace \& World. Inc.,

Murgianto, Sal. 1998. Keragaman dan Silang Budaya. Bandung: MSPI

Murgianto, Sal. 2016. Pertunjukan Budaya dan Akal Sehat. Jakarta: PSFP IKJ.

Sahid, Nur. 2013. Estetika Teater Gandrik Yogyakarta Era Orde Baru Kajian Sosiologi Teater. Yogyakarta: Badan Penerbit ISI Yogyakarta.

Sedyawati, Edy. Seni Pertunjukan Dalam Perspektif Sejarah, dalam Jurnal Masyarakat Seni Pertunjukan Indonesia Th.IX-1998/1999. Bandung: Masyarakat Seni Pertunjukan Indonesia.

Sarumpear, Jan Pieter. 1991. Linguistik di Indonesia-Pengaruh bahasa Makassar terhadap bahasa Aborigin. Jakarta: Masyarakat Linguistik Indonesia

Sugiyati S.A. dkk. 1993. Teater Untuk Dilakoni. Bandung: Studiclub Teater Bandung bekerja sama dengan CV. Geger Sunten.

Anirun, Suyatna. 2009. Melakoni teater. Serpihan Tulisan Tentang Teater. Bandung: Studiclub Teater Bandung.

Yatim, Nurdin. 1991. Pelayaran Teripang Dari Makassar Ke Marege. Makassar: Pemerintah Daerah Propinsi Dati I Sulawesi Selatan.

Yudiaryani. 2015. Rendra dan Teater Mini Kata. Yogyakarta. Galang Pustaka 